\title{
EVALUASI ATAS PENGENDALIAN INTERN PENATAUSAHAAN BARANG MILIK NEGARA BERDASARKAN STANDAR AKUNTANSI PEMERINTAHAN (STUDI KASUS PADA INSPEKTORAT JENDERAL DEPDIKNAS)
}

\author{
Sujatmiko Wibowo \\ Fakultas Ekonomi Universitas Pakuan \\ Email: sujatmiko.wibowo@unpak.ac.id
}

ARTICLE INFO

Article History:

Received 12 August 2018

Revised 23 Sept. 2018

Accepted 1 Oct. 2018

\section{JEL Classification}

H83, M48

\section{Key Word:}

Asset Management, State-Owned Property, and Government Accounting System

\begin{abstract}
Changes in the new paradigm for the management of State-Owned Property along with the issuance of several new regulations governing the management of State-Owned Property issues, has risen a new optimism in the arrangement and management of State-Owned Property that was more orderly, accountable, and transparent. As the Accounting Unit for the Property User (UAKPB), the Inspectorate General of the Ministry of National Education has the responsibility to administer State Property under its control. This study aims to provide a brief overview how the administration of State-Owned Property at the Office of the Inspectorate General of the Ministry of National Education. This study uses descriptive analysis methodology with data collection techniques through literature studies and field research. The results of the study indicate that administration of State-Owned Property at the Office of the Inspectorate General of the Ministry of National Education has not been running well and has not been in accordance with the applicable laws and regulations. Suggestions that can be given are that the Office of the Inspectorate General of the Ministry of National Education establishes the organizational structure of agency accounting units, as well as improving internal control and competency of human resources in order to organize administration of State-Owned Property in a transparent and accountable manner in accordance with existing laws.
\end{abstract}

\section{PENDAHULUAN}

Lahirnya Undang-Undang (UU) Nomor 17 tahun 2003 tentang Keuangan Negara dan UU Nomor 1 tahun 2004 tentang Perbendaharaan Negara mengisyaratkan reformasi di bidang keuangan Negara. Disusul oleh munculnya Peraturan Pemerintah (PP)
Nomor 24 tahun 2005 tentang Standar Akuntansi Pemerintahan serta Peraturan Menteri Keuangan (PMK) Nomor 59/PMK.06/2005 tentang Sistem Akuntansi dan Pelaporan Keuangan Pemerintah Pusat yang menjadi pedoman dalam penyusunan laporan pertanggungjawaban pemerintah atas 
pelaksanaan pengelolaan keuangan Negara. Pengelolaan keuangan negara bukan hanya berhubungan dengan pengelolaan kas namun juga meliputi pengelolaan Barang Milik Negara (BMN), karena BMN merupakan aset negara yang perlu diperhitungkan dan dilaporkan di dalam neraca pemerintah. Tata cara pengelolaan BMN telah diatur sejak dulu, namun hingga sekarang pelaksanaannya dianggap belum seperti yang diharapkan. Untuk itu pemerintah mengeluarkan beberapa peraturan baru yang mengatur masalah pengelolaan BMN. Peraturan-peraturan tersebut diharapkan dapat membawa perbaikan dalam pengelolaan BMN.

Menurut Pardiman (2009), Perubahan paradigma baru pengelolaan Barang Milik Negara/aset negara yang ditandai dengan dikeluarkannya PP Nomor 6 tahun 2006 yang merupakan peraturan turunan UU Nomor 1 tahun 2004 tentang Perbendaharaan Negara, telah memunculkan optimisme baru dalam penataan dan pengelolaan aset negara yang lebih tertib, akuntabel, dan transparan ke depannya. Pengelolaan aset negara yang profesional dan modern dengan mengedepankan good governance di satu sisi diharapkan akan mampu meningkatkan kepercayaan pengelolaan keuangan negara dari masyarakat / stakeholder.

Berdasarkan Prosedur Operasi Standar (POS) Sistem Informasi Manajemen Biro Keuangan Setjen Depdiknas Tahun 2008, Pengelolaan BMN meliputi perencanaan kebutuhan dan penganggaran, pengadaan, penggunaan, pemanfaatan, pengamanan dan pemeliharaan, penilaian, penghapusan, pemindahtanganan, penatausahaan, serta pembinaan, pengawasan, dan pengendalian. Penatausahaan merupakan urat nadi dari keseluruhan fungsi pengelolaan BMN karena melalui penatausahaan yang meliputi kegiatan pembukuan, inventarisasi, serta pelaporan BMN yang melibatkan Sistem Akuntansi Barang Milik Negara (SABMN), akan didapatkan informasi yang memuat jumlah, nilai, jenis, serta kondisi seluruh BMN dari tahun ke tahun termasuk jumlah dan nilai pertambahannya. Informasi yang dihasilkan dari penatausahaan BMN digunakan sebagai dasar dalam pengambilan keputusan dalam perencanaan kebutuhan dan penganggaran, penggunaan, pengawasan, serta fungsi-fungsi lain dalam pengelolaan BMN. Penatausahaan BMN yang baik bukan hanya merupakan tanggung jawab Menteri Keuangan sebagai pengelola BMN yang dikuasakan kepada Direktorat Pengelolaan Barang Milik/Kekayaan Negara, namun juga membutuhkan kesadaran serta peran serta seluruh departemen/lembaga pemerintah baik di pusat maupun di daerah sebagai pengguna BMN.

Inspektorat Jenderal Pendidikan Nasional (Itjen Depdiknas) merupakan salah satu unit utama Depdiknas yang mempunyai fungsi dan tugas melaksanakan pengawasan kinerja, keuangan dan pengawasan di lingkungan Departemen Pendidikan Nasional. Itjen Depdiknas sebagai unit eselon I merupakan Pembantu Pengguna Barang dan juga sebagai Kuasa Pengguna Barang. Berdasarkan temuan Tim Penertiban BMN BPKP tahun 2007, Penatausahaan Barang Milik Negara pada Kantor Itjen Depdiknas masih jauh dari cukup untuk dikategorikan tertib dan akuntabel. Hal ini bisa dilihat dari kurang tertibnya pembukuan, inventarisasi, dan pelaporan BMN yang ada pada Itjen Depdiknas.

Dari temuan Tim Penertiban BMN BPKP tahun 2007, permasalahan yang dihadapi Itjen Depdiknas dalam mengelola barang milik negara adalah:

1. Para penanggung jawab atau fungsi-fungsi organisasi dalam pengelolaan dan penatausahaan barang beserta stafnya tidak berjalan secara optimal;

2. Kurangnya pengetahuan keterampilan petugas pelaksana pengelola barang;

3. Terdapatnya bagian-bagian tertentu yang kelebihan peralatan dan perlengkapan sedangkan di bagian lain kekurangan;

4. Belum semua BMN diberi kode inventaris; 
5. Terdapat BMN dengan kondisi rusak berat belum dihapuskan dari daftar inventaris.

6. Terdapat perbedaan antara Laporan BMN per 31 Desember 2007 dengan Hasil Inventarisasi BPKP tahun 2007.

Munculnya beberapa peraturan baru yang terkait dengan masalah $\mathrm{BMN}$ membawa perubahan dalam pengelolaan $\mathrm{BMN}$, termasuk penatausahaannya. Peraturan-peraturan tersebut adalah PP Nomor 24 tahun 2005, PMK Nomor 59/PMK.06/2005, PMK Nomor 120/PMK.06/2007 dan PP Nomor 6 tahun 2006. Penelitian ini bertujuan untuk mengevaluasi apakah peraturan-peraturan tersebut sudah dapat diterapkan dengan baik dalam pelaksanaan penatausahaan BMN pada Kantor Itjen Depdiknas.

Penelitian ini dibatasi pada hal-hal yang terkait dengan penatausahaan BMN (aset tetap dan persediaan) yang diterapkan pada Itjen Depdiknas pada Tahun Anggaran 2007 ditinjau kesesuaiannya dengan PMK Nomor 59/PMK.06/2005 tentang Sistem Akuntansi dan Pelaporan Pemerintah Pusat (SAPPP), PP Nomor 24 tahun 2005 tentang Standar Akuntansi Pemerintah, PP Nomor 6 tahun 2006 tentang Pengelolaan Barang Milik Negara/Daerah serta PMK Nomor 120/PMK.06/2007 tentang Penatausahaan BMN. Pembahasan dibatasi hanya meliputi struktur organisasi, tugas, dan fungsi yang terkait dengan penatausahaan BMN, pengklasifikasian, kodefikasi, kapitalisasi, serta prosedur penatausahaan BMN.

Penelitian menggunakan metode kualitatif deskriptif, yaitu dengan melakukan pemahaman dan pengevaluasian atau penilaian terhadap masalah-masalah yang terjadi di lapangan. Selanjutnya, dalam pengumpulan data, menggunakan metode wawancara, observasi lapangan dan studi kepustakaan. Disamping itu penelitian juga mempelajari laporan audit eksternal oleh Badan Pemeriksa Keuangan (BPK), Badan Pemeriksa Keuangan dan Pembangunan (BPKP) dan audit internal oleh auditor
Inspektorat Jenderal Wilayah I Depdiknas pada Kantor Itjen Depdiknas.

\section{TINJAUAN PUSTAKA}

\section{Pengertian Barang Milik Negara}

UU Nomor 1 tahun 2004 tentang Perbendaharaan Negara mendefinisikan Barang Milik Negara (BMN) sebagai "semua barang yang dibeli atau diperoleh atas beban Anggaran Pendapatan dan Belanja Negara (APBN) atau berasal dari perolehan lainnya yang sah"1 $^{1}$. Definisi BMN tersebut juga dinyatakan dalam PMK Nomor 59/PMK.06/2005 tentang Sistem Akuntansi dan Pelaporan Keuangan Pemerintah Pusat dan PP Nomor 6 tahun 2006 tentang Pengelolaan Barang Milik Negara/Daerah.

Menurut penjelasan atas PP Nomor 6 tahun 2006, yang dimaksud barang dalam pengertian di atas adalah benda berwujud yang dapat dinilai, dihitung, diukur, dan ditimbang, tidak termasuk uang dan surat berharga. Sedangkan barang yang berasal dari perolehan lainnya yang sah antara lain barang yang diperoleh dari hibah atau sumbangan, pelaksanaan perjanjian atau kontrak, ketentuan undang-undang, atau putusan pengadilan yang telah memperoleh kekuatan hukum tetap.

Menurut Siregar (2004), BMN adalah bagian dari Kekayaan Negara atau Harta Kekayaan Negara (HKN) yang terdiri dari barang bergerak atau barang yang tidak bergerak yang dimiliki, dikuasai oleh instansi pemerintah, yang sebagian atau seluruhnya yang dibeli atas beban Anggaran Pendapatan dan Belanja Negara (APBN) serta dari perolehan yang sah, tidak termasuk kekayaan negara yang dipisahkan (dikelola BUMN) dan kekayaan Pemerintah Daerah (Pemda).

BMN yang dibahas dalam penelitian ini merupakan BMN yang dikuasai oleh kementerian Negara/lembaga sebagai

\footnotetext{
${ }^{1}$ Republik Indonesia, Undang-undang Nomor 1 tahun 2004 tentang Perbendaharaan Negara, pasal 1 ayat 10 .
} 
pengguna barang beserta unit instansi di bawahnya sebagai kuasa pengguna barang, tidak termasuk barang-barang yang dikuasai atau dimiliki oleh pemerintah daerah, Badan Usaha Milik Negara/Daerah (BUMN dan BUMD), serta bank pemerintah dan lembaga keuangan milik pemerintah. Barang-barang yang dikuasai oleh pemerintah daerah, BUMN/BUMD, serta bank pemerintah dan lembaga keuangan milik pemerintah ditatausahakan sendiri oleh instansi yang bersangkutan dengan pedoman tersendiri.

\section{Pengelolaan Barang Milik Negara}

Menurut Siregar (2004), salah satu masalah utama pengelolaan BMN adalah ketidaktertiban dalam pengelolaan data barang. Ini menyebabkan pemerintah kesulitan untuk mengetahui secara pasti BMN yang dikuasainya/dikelolanya, sehingga BMN yang dikelola pemerintah cenderung tidak optimal dalam penggunaannya, serta di sisi lain pemerintah akan mengalami kesulitan untuk mengembangkan pemanfaatan BMN pada masa yang akan datang.

Pengelolaan BMN sebagaimana diatur dalam PP Nomor 6 Tahun 2006, dilaksanakan dengan memperhatikan asas-asas sebagai berikut: Asas Fungsional, Asas Kepastian Hukum, Asas Transparansi, Asas Efisiensi, Asas Akuntabilitas Publik, dan Asas Kepastian Nilai. Sedangkan siklus pengelolaan BMN sebagaimana diamanatkan dalam PP Nomor 6 Tahun 2006 pasal 3 ayat (2) diantaranya adalah: perencanaan kebutuhan dan penganggaran, pengadaan, pemanfaatan, pengamanan dan pemeliharaan, penilaian, penghapusan, pemindahtanganan, penatausahaan serta pembinaan pengawasan pengendalian.

\section{Kapitalisasi Barang Milik Negara}

Kapitalisasi adalah penentuan nilai pembukuan terhadap semua pengeluaran untuk memperolah aset tetap hingga siap pakai, untuk meningkatkan kapasitas/efisiensi, dan/atau memperpanjang umur teknisnya dalam rangka menambah nilai-nilai aset tersebut. $^{2}$ Masalah kapitalisasi aset tetap diatur dalam Keputusan Menteri Keuangan (KMK) Nomor 01/KM.12/2001 tentang Pedoman Kapitalisasi Barang Milik/Kekayaan Negara dalam Sistem Akuntansi Pemerintah.

Menurut KMK Nomor 01/KM.12/2001, pengeluaran yang dikapitalisasi meliputi pengeluaran atas pengadaan tanah, pembelian peralatan dan atau mesin sampai siap pakai, pembuatan peralatan, mesin, dan bangunan, pembangunan gedung dan bangunan, pembangunan jalan/irigasi/jaringan, pembelian aset tetap lainnya hingga siap pakai, serta pembangunan/pembuatan aset tetap lainnya.

Untuk menentukan suatu pengeluaran dikapitalisasi atau tidak, diperlukan batasan jumlah biaya kapitalisasi (capitalization thesholds). Berdasarkan ketentuan dalam KMK Nomor 01/KM.12/2001, pengeluaran yang dikapitalisasi untuk persatuan peralatan dan mesin adalah sama dengan atau lebih besar dari Rp300.000 sedangkan untuk gedung dan bangun an adalah sama dengan atau lebih besar dari Rp10.000.000. Kebijakan tersebut dikecualikan terhadap pengeluaran untuk tanah, jalan/irigasi/jaringan, serta aset tetap lainnya yang berupa koleksi perpustakaan dan barang bercorak kesenian.

Penerapan nilai satuan minimum kapitalisasi dalam penatausahaan BMN mengakibatkan pembukuan dalam Buku Inventaris (BI) dibagi menjadi dua, yaitu:

1. BI Intrakomptabel, untuk mencatat barang tidak bergerak dan barang bergerak yang memenuhi nilai satuan minimum kapitalisasi.

2. BI Ekstrakomptabel, untuk mencatat aset tetap yang tidak memenuhi nilai satuan minimum kapitalisasi.

Masalah kapitalisasi tidak dapat terlepas dari pengakuan dan penilaian $\mathrm{BMN}$ yang diatur dalam PP Nomor 24 tahun 2005 tentang Standar Akuntansi Pemerintahan. Dalam PP

\footnotetext{
2 Ibid, pasal 1 ayat 1.
} 
tersebut, diatur juga masalah penyusutan aset tetap yang belum termuat dalam peraturan sebelumnya.

Menurut Pernyataan Standar Akuntansi Pemerintah (PSAP) Nomor 07 tahun 2005 tang disusun olek Komite Standar Akuntansi Pemerintahan (KSAP), aset tetap diakui saat diterima atau diserahkan hak kepemilikkannya dan/atau saat penguasaannya berpindah dan dinilai berdasarkan biaya perolehan. Apabila tidak memungkinkan, maka aset diukur sebesar nilai wajar pada saat aset tersebut diperoleh.

Menurut Pernyataan Standar Akuntansi Pemerintahan (PSAP) Nomor 7 tahun 2005, Pengeluaran untuk aset tetap yang terjadi setelah perolehan awal yang dapat memperpanjang masa manfaat atau meningkatkan kapasitas dan standar kerja, ditambahkan atau dikapitalisasikan pada nilai tercatat aset tersebut.

Aset selain tanah dan konstruksi dalam pengerjaan dapat disusutkan sesuai dengan sifat dan karakteristik aset tersebut. Metode penyusutan yang dapat digunakan antara lain metode garis lurus, metode saldo menurun ganda, dan metode unit produksi. Kemudian untuk pengkuran selanjutnya, aset tetap disajikan berdasrkan biaya perolehan aset tetap tersebut dikurangi dengan akumulasi penyusutan.

Seperti halnya aset tetap, PSAP Nomor 05 menjelaskan bahwa pengakuan persediaan dilakukan saat persediaan tersebut diterima atau hak kepemilikannya dan/atau hak penguasaannya berpindah. Persediaan diukur sebesar biaya perolehan bila diperoleh dari pembelian, biaya standar bila diperoleh dari donasi atau rampasan. Pada akhir periode akuntansi, persediaan dicatat berdasarkan hasil inventarisasi fisik dan dinilai pada biaya perolehan terakhir.

Berdasarkan Lampiran PMK Nomor 59/PMK.06/2005, barang bersejarah (heritage assets) dibukukan dan disajikan dalam kuantitasnya tanpa nilai karena nilai budaya, lingkungan, pendidikan, dan sejarahnya tidak mungkin secara penuh dilambangkan dengan nilai uang berdasarkan harga pasar maupun harga perolehannya. Biaya untuk perolehan, konstruksi, peningkatan, dan rekonstruksi dibebankan sebagai belanja tahun terjadinya pengeluaran tersebut dan tidak dikapitalisasi menjadi nilai barang atau penambah nilai barang. Apabila suatu aset bersejarah digunakan dalam kegiatan operasional seperti untuk perkantoran misalnya, maka terhadap aset tersebut diterapkan prinsip-prinsip yang berlaku bagi aset tetap yang lain.

\section{Penatausahaan Barang Milik Negara}

Sebagai Pengguna dan Kuasa Pengguna BMN, setiap departemen/lembaga beserta instansi-instansi di bawahnya wajib mengelola BMN yang berada dalam penguasaaannya dengan baik. Salah bentuknya adalah dengan melakukan penatausahaan BMN. Hal ini secara jelas dinyatakan di dalam UU Nomor 1 tahun 2004 tentang Perbendaharan Negara pasal 44 yang menyatakan bahwa "Pengguna barang dan/atau kuasa pengguna barang wajib mengelola dan menatausahakan Barang Milik Negara/Daerah yang berada dalam penguasaannya dengan sebaik-baiknya."3 Selain itu, pasal 51 (2) menyatakan bahwa "Menteri/Pimpinan Lembaga/Kepala satuan kerja perangkat daerah selaku pengguna anggaran menyelenggarakan akuntansi atas transaksi keuangan, aset, utang, dan ekuitas dana, termasuk transaksi pendapatan dan belanja yang berada dalam tanggung jawabnya."4 Tujuan dari penatausahaan BMN antara lain : (a) tertib administrasi barang; (b) penghematan keuangan negara; (c) mengetahui kuantitas dan nilai BMN; dan (d) memudahkan penyelenggaraan pengelolaan BMN.

\footnotetext{
3 Republik Indonesia, Undang-Undang Nomor 1 tahun 2004 tentang Perbendaharaan Negara, pasal 44.

${ }^{4}$ Ibid, pasal 51 ayat 2.
} 
Yang dimaksud dengan penatausahaan BMN adalah: "rangkaian kegiatan yang meliputi pembukuan, inventarisasi, dan pelaporan barang milik negara/daerah sesuai dengan ketentuan yang berlaku." ${ }^{5}$ Dan yang dimaksud dengan inventarisasi adalah "kegiatan untuk melakukan pendataan, pencatatan, dan pelaporan hasil pendataan BMN." ${ }^{16}$ Pembukuan dan pelaporan BMN disebut juga akuntansi BMN, dan pelaksanaannya dilakukan menggunakan suatu sistem yang disebut Sistem Akuntansi Barang Milik Negara (SABMN).

\section{Organisasi dan Dokumentasi dalam Penatausahaan BMN}

Sebelum menelaah proses penatausahaan BMN, kita terlebih dahulu perlu memahami organisasi-organisasi yang bertanggungjawab untuk melaksanakan penatausahaan BMN tersebut. Menurut PMK Nomor 59/PMK.06/2005, organisasi penatausahaan atau unit akuntansi BMN terdiri dari:

1. Unit Akuntansi Kuasa Pengguna Barang (UAKPB), adalah satuan kerja/kuasa pengguna barang yang memiliki wewenang mengurus dan/atau menggunakan BMN serta menguasai anggaran sesuai dengan ketentuan yang berlaku. Penanggung jawab UAKPB adalah kepala kantor/kepala satuan kerja.

2. Unit Akuntansi Pembantu Pengguna Barang Wilayah (UAPPB-W), adalah unit akuntansi BMN pada tingkat kantor wilayah yang melakukan kegiatan penggabungan laporan BMN dari UAKPB. Penanggungjawabnya adalah kepala kantor wilayah.

3. Unit Akuntansi Pembantu Pengguna Barang Eselon I (UAPPB-E1), adalah unit akuntansi BMN pada tingkat eselon I yang melakukan kegiatan penggabungan laporan BMN dari

\footnotetext{
${ }^{5}$ Republik Indonesia, Peraturan Pemerintah Nomor 6 tahun 2006 tentang Pengeloalan Barang Milik Negara/Daerah, pasal 1 ayat 20.

${ }^{6}$ Ibid, Pasal 1 ayat 20.
}

UAPPB-W dan UAKPB yang langsung berada di bawahnya. Penanggungjawabnya adalah pejabat eselon I.

4. Unit Akuntansi Pengguna Barang (UAPB), adalah unit akuntansi BMN pada tingkat kementrian negara/lembaga (pengguna barang) yang melakukan kegiatan penggabungan laporan BMN dari UAPPBE1. Penanggungjawabnya adalah menteri/pimpinan lembaga.

Menurut PP 6 tahun 2006, Penatausahaan BMN berkaitan erat dengan dokumen sumber, catatan, dan laporan. Dokumen sumber adalah setiap dokumen yang berasal dari transaksi BMN yang sumber dananya berasal dari APBN atau perolehan lain yang sah. Yang termasuk dokumen sumber adalah:

1. Saldo awal, yaitu merupakan catatan dan/atau laporan BMN periode seblumnya.

2. Perolehan; pengembangan, dan penghapusan melalui: Berita Acara Serah Terima (BAST) Barang; bukti kepemilikan barang; Surat Perintah Membayar (SPM), Surat Perintah Pencairan Dana (SP2D); faktur pembelian; kuitansi; surat keputusan penghapusan; surat keputusan pengadilan; serta dokumen lain yang sah.

Berdasarkan dokumen sumber, data transaksi dibukukan dan diolah dalam SABMN. Transaksi yang berkaitan dengan BMN terdiri dari:

1. Perolehan, meliputi pembelian, transfer masuk, hibah, rampasan, penyelesaian pembangunan, pembatalan penghapusan, dan reklasifikasi masuk.

2. Perubahan, meliputi pengurangan, pengembangan, perubahan kondisi, koreksi perubahan nilai dan kuantitas.

3. Penghapusan, meliputi penghapusan, transfer keluar, hibah, reklasifikasi keluar, dan koreksi pencatatan.

Sedangkan menurut PMK Nomor 59/PMK.06/2005, formulir atau catatan yang digunakan untuk menatausahakan BMN antara lain: 
1. Buku Inventaris (BI) Intrakomptabel, yaitu buku yang digunakan untuk mencatat barang inventaris (aset tetap) milik negara pada tingkat UAKPB yang memenuhi kriteria kapitalisasi, disusun dalam klasifikasi sub-sub kelompok barang.

2. Buku Inventaris (BI) Ekstrakomptabel, yaitu buku yang digunakan untuk mencatat barang inventaris milik negara pada tingkat UAKPB yang tidak memenuhi kriteria kapitalisasi, disusun dalam klasifikasi subsub kelompok barang.

3. Buku Barang Bersejarah, yaitu buku yang digunakan untuk mencatat BMN pada UAKPB yang memenuhi kriteria aset bersejarah (herritage aset), disusun dalam klasifikasi sub-sub kelompok barang.

4. Buku Persediaan, yaitu buku yang digunakan untuk mencatat semua barang persediaan yang masih tersimpan dalam gudang persediaan yang menjadi tanggung jawab bendahara atau kepala gudang. Buku persediaan dibuat dalam bentuk kartu untuk setiap jenis barang dan dikelola oleh petugas yang menangani persediaan.

5. Kartu Inventaris Barang (KIB), yaitu kartu yang digunakan untuk mencatat secara lengkap identitas barang inventaris milik negara pada tingkat UAKPB yang memiliki kekhususan dan tidak dapat dicatat dalam Daftar Inventaris Ruangan (DIR), yang karena sifatnya memerlukan penanganan khusus. Ada beberapa KIB, antara lain: (1) KIB tanah; (2) KIB bangunan gedung; (3) KIB alat angkutan bermotor; (4) KIB alat persenjataan.

6. Daftar Inventaris Ruangan (DIR), yaitu daftar yang digunakan untuk mencatat semua barang inventaris yang berada dalam satu ruangan. DIR ditandatangani oleh penanggung jawab ruangan dan penanggung jawab UAKPB.

7. Daftar Inventaris Lainnya (DIL), yaitu daftar yang digunakan untuk mencatat barang inventaris yang tidak dapat dicatat dalam DIR atau KIB yang karena tidak tetap berada dalam ruangan, seperti sepeda, gerobak dorong, pompa air di halaman kantor, hydrant di luar gedung, tiang bendera di halaman gedung, dan sebagainya.

8. Laporan Kondisi Barang (LKB), yaitu daftar untuk mencatat kondisi barang, apakah dalam keadaan baik, rusak ringan, atau rusak berat.

9. Laporan Barang Milik Negara, yaitu laporan yang menyajikan posisi BMN pada awal dan akhir suatu periode serta mutasi BMN yang terjadi selama periode tersebut. Ada dua macam laporan BMN, yaitu laporan BMN semesteran dan laporan BMN tahunan.

\section{Prosedur Penatausahaan BMN}

\section{Inventarisasi BMN}

Menurut PP 6 tahun 2006, inventarisasi adalah kegiatan mendata, mencatat, dan melaporkan hasil pendataan BMN yang bertujuan untuk membandingkan catatan dengan jumlah, nilai, kondisi, dan keberadaan seluruh BMN yang dikuasai oleh UAKPB. Inventarisasi dapat dilakukan secara rutin maupun sewaktu-waktu apabila diperlukan dengan membentuk tim inventarisasi. Masalah inventarisasi diatur dalam PP Nomor 6 tahun 2006 dan untuk pelaksanaan teknisnya mengacu pada Keputusan Kepala Badan Administrasi Keuangan Negara (BAKUN) No. KEP-11/AK/2003 tentang Pedoman Teknis Akuntansi Barang Milik Negara pada Kementerian Negara/Lembaga.

Menurut PP Nomor 6 tahun 2006, inventarisasi terhadap BMN yang berupa persediaan dan konstruksi dalam pengerjaan dilakukan oleh pengguna barang setiap tahun. Sedangkan untuk BMN selain itu, inventaris asi dilakukan minimal sekalidalam lima tahun. Kemudian, laporan hasil inventarisasi wajib dilaporkan kepada pengelola barang selambatlambatnya tiga bulan setelah selesainya inventarisasi.

Inventarisasi yang diatur dalam Keputusan Kepala BAKUN Nomor KEP- 
11/AK/2003 dilaksanakan dalam tiga tahap, yaitu:

a. Persiapan, meliputi pembentukan tim inventarisasi, pembagian tugas, dan penyusunan jadwal.

b. Pelaksanaan, meliputi penghitungan jumlah, penentuan kondisi, pencatatan dan pembuatan laporan hasil inventarisasi, serta pembuatan daftar barang yang tidak ditemukan, belum dicatat, dan rusak berat.

c. Tindaklanjut, meliputi penelusuran barang yang tidak ditemukan, pencatatan hasil inventarisasi ke dalam SABMN, serta pengusulan penghapusan untuk barang yang rusak berat.

Salah satu hal yang didata dalam pelaksanaan inventarisasi adalah kondisi barang. Berdasarkan kondisinya, BMN dikelompokkan menjadi tiga, yaitu baik, rusak ringan, dan rusak berat. Penentuan kondisi barang dilakukan dengan mengacu pada KMK Nomor 01/KM.12/2001.

\section{Pembukuan dan Pelaporan BMN}

Kegiatan lain dalam penatausahaan BMN adalah pembukuan dan pelaporan, atau disebut juga akuntansi BMN. Pembukuan dan pelaporan $\mathrm{BMN}$ yang berupa aset tetap dilakukan secara terkomputerisasi melalui Sistem Akuntansi Barang Milik Neg\ara (SABMN). Hal ini diatur dalam PMK Nomor 59/PMK.06/2005 dan kebijakan akuntansinya diatur dalam PP Nomor 24 tahun 2005.

Sebagai Unit Akuntansi Kuasa Pengguna Barang (UAKPB), Inspektorat Jenderal Depdiknas mempunyai tugas sebagai berikut:

1. Proses bulanan dan semesteran, terdiri dari:

a. Membukukan data transaksi BMN ke dalam (BI) intrakomptabel, BI ekstrakomptabel, buku barang bersejarah, dan buku persediaan berdasarkan dokumen sumber.

b. Membuat dan/atau memutakhirkan KIB, DIR, dan DIL.

c. Membuat laporan BMN pada akhir semester. d. Meminta pengesahan penanggung jawab UAKPB atas laporan BMN.

e. Menyampaikan data transaksi BMN kepada unit akuntansi keuangan.

f. Menyampaikan laporan BMN beserta ADK kepada unit akuntansi barang di atasnya.

g. Mengarsipkan laporan BMN secara tertib.

2. Proses akhir periode akuntansi, yang meliputi:

a. Menginstruksikan kepada setiap penanggung jawab ruangan untuk melakukan pengecekan ulang kondisi barang yang berada di ruangan masingmasing.

b. Mencatat perubahan kondisi barang yang telah disahkan oleh penanggung jawab ruangan.

c. Membuat Laporan Kondisi Barang (LKB).

d. Meminta pengesahan penanggung jawab unit akuntansi barang tersebut atas LKB yang dibuat.

e. Membuat laporan BMN tahunan berdasarkan saldo $\mathrm{BI}$ intrakomptabel, $\mathrm{BI}$ ekstrakomptabel, dan buku barang bersejarah.

f. Meminta persetujuan penanggung jawab UAKPB atas laporan BMN.

g. Menyampaikan laporan BMN tahunan dan LKB beserta ADK ke unit akuntansi BMN di atasnya.

h. Mengarsipkan BI intrakomptabel, BI ekstrakomptabel, buku barang bersejarah, salinan LKB, dan salinan laporan BMN secara tertib.

i. Melakukan proses backup data dan tutup tahun.

\section{Pengendalian Internal}

\section{Unsur Pengendalian Internal}

Sawyer dalam Panggabean (2014) mengidentifikasi Sistem Pengendalian Internal terdiri dari lima unsur yang saling berkaitan, yaitu (1) lingkungan pengendalian (control environment); (2) penaksiran risiko (risk assesment); (3) aktivitas pengendalian (control 
activities); (4) informasi dan komunikasi (information and communication); dan (5) pemantauan (monitoring). Kelima unsur tersebut bersumber dari cara manajemen atau pimpinan menyelenggarakan tugasnya dan oleh karena itu komponen tersebut menyatu dan terjalin dalam proses manajemen.

Menurut Committee of Sponsoring Organizations of the Treadway Commission (COSO, 1992), pengendalian internal adalah proses, karena hal tersebut menembus kegiatan operasional organisasi dan merupakan bagian integral dari kegiatan manajemen dasar. Pengendalian internal hanya dapat menyediakan keyakinan memadai, bukan keinginan mutlak. Sejalan dengan COSO, pengendalian internal dalam lingkungan Depdiknas diatur dalam UU Nomor 1 tahun 2004 tentang perbendaharaan negara yang dijabarkan lebih lanjut dalam PP Nomor 60 tahun 2008 tentang sistem pengendalian internal pemerintah (SPIP), terdiri atas lima komponen yang saling terkait, yaitu:

a. Lingkungan Pengendalian (Control Environment)

Manajemen puncak dalam suatu organisasi bertanggungjawab untuk menyatakan dengan jelas nilai-nilai integritas dan kegiatan tidak etis yang tidak dapat ditoleransi.

b. Penilaian Risiko (Risk Assessment).

Seluruh organisasi menghadapi berbagai macam risiko dari luar dan dalam yang harus diidentifikasi, dianalisis dan dieliminasi. Penilaian risiko adalah proses mengidentifikasi suatu risiko, menganalisis risiko, mengestimasi signifikansi risiko, menilai kemungkinan terjadinya risiko, dan mengembangkan tindakan khusus yang diperlukan untuk mengurangi risiko tersebut ke tingkat yang dapat diterima.

c. Aktivitas Pengendalian (Control Activities)

Aktivitas pengendalian adalah kebijakan dan prosedur yang telah ditetapkan yang dapat membantu meyakinkan manajemen bahwa arahannya telah dijalankan.
Aktivitas pengendalian membantu meyakinkan bahwa tindakan yang diperlukan telah diambil dalam menghadapi risiko sehingga tujuan entitas dapat tercapai.

d. Informasi dan Komunikasi (Information and Communication)

Informasi yang bersangkutan harus diidentifikasi, tergambar dan terkomunikasi dalam sebuah form dan timeframe yang memungkinkan orang-orang menjalankan tanggungjawabnya.

e. Pemantauan (Monitoring).

Sistem pengendalian internal perlu diawasi secara berkesinambungan dari waktu ke waktu untuk menentukan kualitas kinerja pengendalian internal sehingga dapat ditentukan apakah operasi pengendalian memerlukan modifikasi atau perbaikan. Penyimpangan yang terjadi dilaporkan kepada Direksi dan tembusannya disampaikan kepada Komite Audit.

\section{Pengendalian Internal BMN}

Murtanto (2005) menyatakan bahwa pengendalian internal secara luas didefinisikan secara luas sebagai proses yang dipengaruhi oleh dewan komisaris suatu entitas, manajemen dan personel lain dirancang untuk memberi keyakinan yang memadai berkaitan dengan pencapaian tujuan.

Menurut Biro Keuangan Setjen Depdiknas (2008), dalam penyelenggaraan pelaporan keuangan pengendalian internal memegang peranan penting agar dalam pelaksanaan anggaran dapat efisien dan efektif serta akuntabel. Demikian juga untuk BMN yang merupakan kekayaan Negara sehingga dapat diselamatkan dari penggunanaan yang tidak semestinya dan informasi tentang BMN tersebut dapat dilaporkan dengan transparan serta akurat sesuai prinsip Standar Akuntansi Pemerintahan.

Berdasarkan Prosedur Operasi Standar (POS) Sistem Informasi Manajemen Biro Keuangan Setjen Depdiknas Tahun 2008, 
Pengendalian internal dalam pengelolaan BMN di lingkungan Depdiknas, diantaranya adalah:

a. Penyusunan laporan keuangan dilakukan dengan berpedoman pada prinsip: ketaatan, konsistensi, kemampubandingan, materialitas, obyektif dan kelengkapan.

b. Terdapat pemisahan tugas dan fungsi yang jelas antara operator computer, petugas verifikasi dan petugas administrasi.

\section{Akuntansi Pemerintahan}

Menurut Mursyidi (2009), akuntansi pemerintahan merupakan mekanisme akuntansi yang memproses transaksi keuangan yang berkaitan dengan pengelolaan keuangan negara baik tingkat pusat maupun tingkat daerah.

Hasanah (2016) menyatakan bahwa akuntansi pemerintahan suatu aktivitas pemberian jasa untuk menyediakan informasi keuangan pemerintah berdasarkan proses pencatatan, pengklasifikasian, pengikhtisaran, suatu transaksi keuangan pemerintah serta pentafsiran atas informasi keuangan. Pelaksanaan akuntansi pemerintahan merupakan perwujudan dari UU Nomor 1 Tahun 2004 dimana semua penyelenggaraan akuntansi atas transaksi keuangan, aset, utang, dan ekuitas dana, termasuk transaksi pendapatan dan belanja. Dalam penyusunan laporan keuangan pemerintah menggunakan Standar Akuntansi Pemerintahan.

Standar Akuntansi Pemerintahan (SAP) ditetapkan dengan Peraturan Pemerintah No. 71 Tahun 2010 sebagai pengganti Peraturan Pemerintah No. 24 Tahun 2005. SAP dinyatakan dalam bentuk Pernyataan Standar Akuntansi Pemerintahan (PSAP), dilengkapi dengan Pengantar Standar Akuntansi Pemerintahan dan disusun mengacu kepada Kerangka Konseptual Akuntansi Pemerintahan.

\section{METODE PENELITIAN}

Jenis Penelitian
Penelitian ini menggunakan metode penelitian kualitatif deskriptif, yang merupakan jenis penelitian dimana data yang dikumpulkan berupa kata-kata, gambar, dan bukan angka-angka, dan semua data yang dikumpulkan berkemungkinan menjadi kunci terhadap apa yang sudah diteliti (Moleong, 2010).

Pendekatan kualitatif deskriptif dalam penelitian ini bertujuan untuk mendeskripsikan dan melakukan analisis terhadap realita dari pelaksanaan penatausahaan BMN di lingkungan Itjen Depdiknas. Selain itu juga untuk memberikan saran dan masukan terkait penatausahaan BMN ke depan.

\section{Metode Pendekatan Penelitian}

Pendekatan yang digunakan dalam penelitian ini adalah menggunakan pendekatan studi kasus. Studi kasus merupakan salah satu strategi dan metode analisis data kualitatif yang menekankan pada kasus-kasus yang terjadi pada obyek analisis (Bungin, 2007). Tujuan studi kasus adalah untuk melakukan penyelidikan secara mendalam mengenai subyek tertentu untuk memberikan gambaran yang lengkap mengenai subyek tertentu (Indriantoro, 2002).

Peneliti mengamati langsung dan berada di dalam lingkungan obyek penelitian bersama informan di dalamnya sehingga gambaran lengkap yang dibutuhkan dalam penelitian ini dapat diperoleh dari sumber yang dapat dipertanggungjawabkan.

\section{Obyek Penelitian}

Obyek penelitian studi kasus ini adalah Inspektorat Jenderal Depertemen Pendidikan Nasional (Itjen Depdiknas) yang merupakan salah satu unit Eselon I di lingkungan Kementerian Pendidikan Nasional.

\section{Desain Penelitian}

Desain penelitian adalah suatu rancangan yang menggambarkan bagaimana penelitian itu dilakukan guna mendapatkan apa yang 
menjadi tujuan dari penelitian. Desain penelitian merupakan kaitan logis antara data empiris dengan pertanyaan awal penelitian, terutama konklusi-konklusinya (Yin, 2009). Desain penelitian yang digunakan dalam penelitian ini bersifat penjelasan (explanatory research).

\section{Jenis dan Sumber Data}

Dalam penelitian ini jenis dan sumber data yang digunakan adalah:

\section{Data primer}

Data primer yang digunakan peneliti antara lain: laporan keuangan semesteran dan tahunan serta catatan hasil wawancara dan hasil observasi ke lapangan secara langsung dalam bentuk catatan tentang situasi dan kejadian. Kriteria informan dari penelitian ini adalah pejabat dan pengelola BMN Itjen Depdiknas yang telah bertugas selama lebih dari 2 tahun.

2. Data sekunder

Data ini digunakan untuk pelengkap data primer yang diperoleh baik dari dokumen, catatan transkrip, internet dan sebagainya. Data sekunder tersebut antara lain berupa: Undang-Undang dan Peraturan terkait yang berhubungan dengan pengelolaan BMN dan penatausahaan BMN di Indonesia, struktur organisasi Kerja Itjen Depdiknas, laporan hasil audit dari internal maupun eksternal, serta dokumen-dokumen lain yang mendukung baik dari internal ataupun dokumen yang berasal dari sumber eksternal.

\section{Metode Pengumpulan data}

Metode pengumpulan data dalam penelitian kualitatif ini adalah sebagai berikut:

1. Pengamatan/observasi lapangan yang bertujuan untuk mengamati dan mencatat gejala-gejala yang tampak pada obyek penelitian pada saat keadaan atau situasi yang alami atau yang sebenarnya sedang berlangsung (Widyantoro, 2009 dalam Harwida, 2014). Peneliti melakukan observasi /pengamatan lapangan pada obyek penelitian yaitu pada Itjen Depdiknas.

2. Wawancara, yaitu wawancara yang bertujuan mencatat opini, perasaan, emosi, dan hal lain yang berkaitan dengan individu yang yang ada dalam organisasi (Chariri, 2009). Jenis wawancara yang digunakan adalah wawancara bertahap atau wawancara tidak terstruktur. Selain itu, jenis wawancara yang digunakan adalah wawancara terbuka (open interview) yaitu suatu bentuk wawancara yang menghendaki jawaban yang luas dari informan dan tidak terbatas (Koentjaningrat, 2011 dalam Qolbi, 2012). Kriteria informan dari penelitian ini adalah Pejabat dan Pengelola BMN Itjen Depdiknas yang telah bertugas selama lebih dari 2 tahun.

\section{Prosedur Pengumpulan data}

Prosedur pengumpulan data dalam penelitian ini adalah sebagai berikut:

1. Survei pendahuluan. Yaitu untuk menggali informasi melalui observasi pada obyek yang akan diteliti untuk memperoleh gambaran tentang obyek penelitian. Survai ini dilakukan pada awal Semester II Tahun 2007 atau sekitar bulan Juli 2007.

2. Survei kepustakaan. Yaitu mengumpulkan dan mempelajari data yang diperoleh dari buku-buku, jurnal atau artikel ilmiah maupun aturan perundang-undangan yang disesuaikan dengan teori-teori pendukung.

3. Pengumpulan data lapangan. Yaitu dengan melakukan observasi, wawancara dan dokumen yang didapat. Dalam melakukan observasi, peneliti melakukan wawancara secara mendalam kepada pengelola BMN dan pejabat yang bertanggungjawab atas pengelolaan BMN untuk memperoleh informasi yang terkait dengan tujuan penelitian. Dimana wawancara dilakukan 
datang dan pergi guna mendapatkan waktu yang lebih lama, agar peneliti bisa menyimpulkan dan menulis hasil wawancara tersebut (Bungin, 2007). Pengumpulan data lapangan dilakukan pada awal tahun 2008 sampai dengan akhir bulan Juni tahun 2008.

\section{Teknis Analisis Data}

Pada tahap awal, penelitian ini mengumpulkan data dari beberapa sumber terkait. Data yang berhasil diperoleh kemudian dilakukan telaah dokumen secara cermat dan diproses dengan memperdalam informasi atau data dari informan yang kompeten, baik yang diperoleh dari hasil wawancara maupun survey langsung lapangan serta dokumen yang mendukung penelitian. Dari penggabungan hasil wawancara maupun data yang terkumpul tersebut, kemudian direviu kembali apabila terdapat data yang penting atau relevan dengan penelitian maka dibuat cacatan kecil /notulensi.

Tahapan analisis data kualitatif (Seiddel 1998 dalam Moleong 2010), prosesnya berjalan sebagai berikut:

1. Mencatat yang menghasilkan catatan lapangan, dengan hal itu diberi kode agar sumber datanya tetap dapat ditelusuri.

2. Mengumpulkan, memilah-milah, mengklasifikasikan, membuat ikhtisar, dan membuat indeksnya.

3. Berpikir, dengan jalan membuat agar kategori data itu mempunyai makna, mencari dan menemukan pola dan hubungan-hubungan, dan membuat temuan-temuan umum.

\section{PEMBAHASAN}

\section{Obyek Penelitian}

Organisasi penatausahaan BMN Departemen Pendidikan Nasional dapat dibedakan menjadi tiga, yaitu unit penatausahaan BMN pada pengelola barang/departemen, unit penatausahaan BMN pada pengguna barang/eselon I, dan unit penatausahaan BMN pada kuasa pengguna barang/satuan kerja.

Inspektorat Jenderal Depdiknas merupakan salah satu unit utama/eselon I di lingkungan Depdiknas, yang terbentuk berdasarkan Peraturan Mendiknas Nomor 12 tahun 2005 Tentang Organisasi dan Tata Kerja Inspektorat Jenderal Depdiknas. Berdasarkan Permendiknas tersebut, Inspektorat Jenderal mempunyai tugas melakukan pengawasan fungsional, sedangkan fungsinya adalah sebagai: Perumusan kebijakan, Pelaksanaan Pengawasan Fungsional, Pelaksanaan Fasilitasi, Pelaksanaan Urusan Administrasi, dan Pengamanan Kebijakan Menteri.

Itjen Depdiknas dipimpin oleh seorang Inspektur Jenderal. Dalam menjalankan tugas dan fungsinya, Itjen berada di bawah dan bertanggungjawab langsung kepada Menteri Pendidikan Nasional, serta membawahi unitunit eselon II, yakni 1 Sekretariat Inspektorat Jenderal dan 4 Inspektorat.

Sesuai dengan struktur organisasi akuntansi BMN, Itjen memegang dua peran, yaitu sebagai Unit Akuntansi Pembantu Pengguna Barang Eselon I (UAPPB-E1) sekaligus sebagai Unit Akuntansi Kuasa Pengguna Barang (UAKPB). Peran UAKPB dipegang oleh Bagian Umum dengan Kepala Bagian Umum sebagai penanggungjawabnya. Bagian Umum sebagai UAKPB bertanggungjawab atas $\mathrm{BMN}$ yang dikuasai oleh Itjen Depdiknas dari awal perolehan, penatausahaan sampai dengan pertanggungjawabannya.

Sedangkan peran UAPPB-E1 dipegang oleh Bagian Umum dan Sekretaris Itjen Depdiknas sebagai Penangungjawab. Sekretariat Itjen bertanggungjawab atas BMN yang dikuasai Itjen Depdiknas secara keseluruhan.

\section{Evaluasi atas Struktur Organisasi, Tugas dan Fungsi}

Berkaitan dengan penatausahaan BMN, Itjen Depdiknas memegang peran sebagai Unit Akuntansi Pembantu Pengguna Barang Eselon 
I (UAPPB-E1) sekaligus sebagai Unit Akuntansi Kuasa Pengguna Barang (UAKPB). Hal ini sesuai dengan struktur organisasi akuntansi BMN yang diatur dalam PMK Nomor 59/PMK.06/2005 tentang Sistem Akuntansi dan Pelaporan Keuangan Pemerintah Pusat.

Menurut PMK tersebut, organisasi akuntansi BMN terdiri dari Unit Akuntansi Pengguna Barang (UAPB), Unit Akuntansi Pembantu Pengguna Barang Eselon I (UAPPBE1), Unit Akuntansi Pembantu Pengguna Barang Wilayah (UAPPB-W), dan Unit Akuntansi Kuasa Pengguna Barang (UAKPB). Dalam hubungannya dengan Itjen Depdiknas, yang berperan sebagai UAPB adalah Departemen Pendidikan Nasional, dalam hal ini adalah Sekretariat Jenderal Departemen Pendidikan Nasional. Kemudian Sekretariat Itjen Depdiknas sebagai UAPPB-E1 dan Bagian Umum sebagai UAKPB.

Penanggung jawab penatausahaan BMN pada Itjen Depdiknas adalah Inspektur Jenderal selaku pejabat eselon I. Hal ini sesuai dengan ketentuan yang diatur dalam UU Nomor 1 tahun 2004 tentang Perbendaharaan Negara, yang pada pasal 42(3) dinyatakan bahwa kepala kantor dalam lingkungan kementerian negara/lembaga adalah Kuasa Pengguna Barang dalam lingkungan kantor yang bersangkutan. Kemudian pasal 44 menyatakan bahwa Pengguna Barang dan/atau Kuasa Pengguna Barang wajib mengelola dan menatausahakan BMN/daerah yang berada dalam penguasaannya dengan sebaik-baiknya.

Sebagai UAPPB-E1, Itjen berkewajiban untuk melaporkan BMN yang dikuasai dan digunakan dalam operasionalnya. Disamping itu Itjen Depdiknas juga berperan sebagai UAKPB yang bertugas melakukan pelaporan BMN di tingkat satker. Namun kedua peran tersebut hanya dikerjakan oleh Subbagian Tata Usaha Bagian Umum, dan hanya dibedakan oleh penanggungjawabnya saja.

\section{Evaluasi atas Pengklasifikasian, Kodefikasi, dan Kapitalisasi BMN \\ Pengklasifikasian BMN pada Itjen} Depdiknas sudah sesuai dengan PP Nomor 24 tahun 2005 tentang Standar Akuntansi Pemerintahan yang mengatur perlakuan akuntansi untuk BMN dengan membedakannya menjadi aset tetap dan persediaan. Menurut PP Nomor 24 tahun 2005, aset pemerintah yang disajikan dalam neraca terdiri dari aset tetap dan aset lancar.

Pemberian kodefisikasi BMN pada Itjen Depdiknas tidak sesuai dengan ketentuan yang ditetapkan dalam KMK Nomor 18/KMK.018/1999 dan PMK Nomor $59 /$ PMK.06/2005. Kode yang ada hanya mencantumkan kode barang dan tidak mencantumkan kode lokasi. Disamping itu, belum semua BMN dibawah penguasaan Itjen Depdiknas diberikan kodefikasi sesuai kode masing-masing barang.

Selain mengacu pada KMK Nomor 01/KM.12/2001, masalah kapitalisasi BMN juga berpedoman pada PP Nomor 24 tahun 2005. PP ini mengatur perlakuan akuntansi bagi BMN yang meliputi aset tetap dan persediaan, mulai dari pengakuan awal saat perolehan, pengukuran dan penilaiannya, pengeluaran setelah perolehan (subsequent expenditure), hingga penyusutan untuk aset tetap. Pada Itjen Depdiknas, BMN berupa aset tetap serta persediaan diakui dan mulai dibukukan ketika BMN yang bersangkutan diterima beserta bukti kepemilikannya seperti Berita Acara Serah Terima (BAST) barang, kuitansi, faktur pembelian, dan sebagainya. $\mathrm{Hal}$ ini sesuai dengan yang dinyatakan dalam PP Nomor 24 tahun 2005 bahwa pengakuan aset tetap akan sangat andal bila aset tetap telah diterima atau diserahkan hak kepemilikannya dan atau pada saat penguasaannya berpindah. Demikian juga untuk persediaan pada Itjen Depdiknas diakui pada saat diterima atau hak kepemilikannya dan/atau kepenguasaannya berpindah. 
Sujatmiko Wibowo: Evaluasi atas Pengendalian Intern...

\section{Evaluasi Penatausahaan BMN berdasarkan PMK Nomor 59/PMK.06/2005}

Menurut PMK Nomor 59/PMK.06/2005, penatausahaan BMN dilaksanakan dengan aplikasi SABMN dengan tujuan untuk menghasilkan informasi yang diperlukan sebagai alat pertanggungjawaban atas pelaksanaan APBN serta pengelolaan/pengendalian BMN yang dikuasai oleh suatu unit akuntansi barang. Penatausahaan BMN pada Kantor Itjen Depdiknas belum seluruhnya sesuai dengan PMK Nomor 59/PMK.06/2005, diantaranya adalah seperti pada Tabel 1.

Table 1. Perbandingan antara PMK Nomor 59/PMK.06/2007 dengan Penatausahaan BMN Itjen Depdiknas

\begin{tabular}{|c|c|c|}
\hline $\begin{array}{c}\text { PMK } \\
\text { No.59/PMK.06/200 } \\
5 \text { tentang SAPKP }\end{array}$ & $\begin{array}{c}\text { Penatausahaa } \\
\text { n BMN Itjen } \\
\text { Depdiknas }\end{array}$ & Hasil Evaluasi \\
\hline \multicolumn{3}{|l|}{ Pasal 16 ayat 1} \\
\hline $\begin{array}{l}\text { Setiap UAPKB } \\
\text { melaksanakan } \\
\text { proses akuntansi } \\
\text { atas dok. Sumber } \\
\text { dalam rangka } \\
\text { menghasilkan data } \\
\text { transaksi BMN dan } \\
\text { Laporan BMN }\end{array}$ & $\begin{array}{l}\text { Itjen } \\
\text { Depdiknas } \\
\text { sudah } \\
\text { melaksanakan } \\
\text { proses } \\
\text { akuntansi dan } \\
\text { menghasilkan } \\
\text { data transaksi } \\
\text { dan laporan } \\
\text { BMN }\end{array}$ & $\begin{array}{l}\text { Penatausahaa } \\
\text { n BMN Itjen } \\
\text { Depdiknas } \\
\text { sudah sesuai } \\
\text { ketentuan } \\
\text { yang berlaku }\end{array}$ \\
\hline $\begin{array}{l}\text { Pasal } 16 \text { ayat } 2 \\
\text { Data transaksi BMN } \\
\text { disampaikan UAKPA } \\
\text { Setiap bulan dlm } \\
\text { bentuk ADK }\end{array}$ & $\begin{array}{l}\text { Itjen } \\
\text { Depdiknas } \\
\text { belum } \\
\text { menyampaikan } \\
\text { data transaksi } \\
\text { BMN ke UAKPA } \\
\text { Setiap bulan }\end{array}$ & $\begin{array}{l}\text { Penatausahaa } \\
\text { n BMN Itjen } \\
\text { Depdiknas } \\
\text { belum sesuai } \\
\text { ketentuan } \\
\text { yang berlaku }\end{array}$ \\
\hline $\begin{array}{l}\text { Pasal } 16 \text { ayat } 3 \\
\text { Data transaksi BMN } \\
\text { disampaikan UAPPB- } \\
\text { E1 setiap semester }\end{array}$ & $\begin{array}{l}\text { Itjen } \\
\text { Depdiknas } \\
\text { sudah } \\
\text { menyampaikan } \\
\text { data transaksi } \\
\text { BMN ke } \\
\text { UAPPB-E1 } \\
\text { Setiap } \\
\text { semester }\end{array}$ & $\begin{array}{l}\text { Penatausahaa } \\
\text { n BMN Itjen } \\
\text { Depdiknas } \\
\text { sudah sesuai } \\
\text { ketentuan } \\
\text { yang berlaku }\end{array}$ \\
\hline
\end{tabular}

\begin{tabular}{|c|c|c|}
\hline $\begin{array}{c}\text { PMK } \\
\text { No.59/PMK.06/200 } \\
5 \text { tentang SAPKP }\end{array}$ & $\begin{array}{l}\text { Penatausahaa } \\
\text { n BMN Itjen } \\
\text { Depdiknas }\end{array}$ & Hasil Evaluasi \\
\hline $\begin{array}{l}\text { UAPPB-E1 } \\
\text { menyusun Lap BMN } \\
\text { Eselon I } \\
\text { Lap BMN Eselon I } \\
\text { disampaikan ke } \\
\text { UAPB r Setiap } \\
\text { semester }\end{array}$ & $\begin{array}{l}\text { Itjen } \\
\text { Depdiknas } \\
\text { sudah } \\
\text { menyusun Lap } \\
\text { BMN Eselon I } \\
\text { dan } \\
\text { menyampaik } \\
\text { an ke UAPB } \\
\text { Setiap } \\
\text { semester }\end{array}$ & $\begin{array}{l}\text { Penatausahaa } \\
\text { n BMN Itjen } \\
\text { Depdiknas } \\
\text { sudah sesuai } \\
\text { ketentuan } \\
\text { yang berlaku }\end{array}$ \\
\hline $\begin{array}{l}\text { Pasal } 21 \text { ayat } 1 \text { \& } \mathbf{2} \\
\text { Prosedur } \\
\text { pencatatan SABMN } \\
\text { dilaksanakan sesuai } \\
\text { prosedur } \\
\text { Laporan BMN dibuat } \\
\text { sesuai format dan } \\
\text { bentuk baku yang } \\
\text { ditentukan }\end{array}$ & $\begin{array}{l}\text { Itjen } \\
\text { Depdiknas } \\
\text { belum } \\
\text { melaksanakan } \\
\text { pencatatan } \\
\text { SABMN sesuai } \\
\text { prosedur dan } \\
\text { belum } \\
\text { menyusun } \\
\text { Laporan BMN } \\
\text { sesuai format } \\
\text { dan bentuk } \\
\text { baku }\end{array}$ & $\begin{array}{l}\text { Penatausahaa } \\
\text { n BMN Itjen } \\
\text { Depdiknas } \\
\text { belum sesuai } \\
\text { ketentuan } \\
\text { yang berlaku }\end{array}$ \\
\hline
\end{tabular}

Sumber: diolah dari berbagai sumber

\section{Evaluasi Penatausahaan BMN berdasarkan PMK Nomor 120/PMK.06/2007}

Menurut PMK Nomor 120/PMK.06/2007, penatausahaan BMN meliputi pembukuan, inventarisasi dan Pelaporan BMN. Dalam penatausahaan $\mathrm{BMN}$ ini termasuk di dalamnya melaksanakan tugas dan fungi akuntansi BMN. Hasil penatausahaan BMN ini nantinya dapat digunakan dalam rangka perencanaan kebutuhan pengadaan dan pemeliharaan $\mathrm{BMN}$ Setiap tahun sebagai bahan penyusunan rencana anggaran dan pengamanan administrasi BMN.

Penatausahaan BMN pada Kantor Itjen Depdiknas belum seluruhnya sesuai dengan PMK Nomor 120/PMK.06/2007, diantaranya adalah seperti pada Tabel 2.

Tabel 2. Perbandingan PMK Nomor 120/PMK.06/2007 dengan Penatausahaan Itjen Depdiknas 


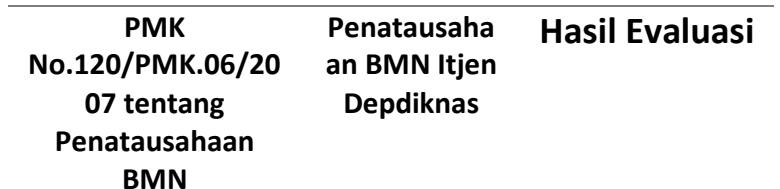

\begin{tabular}{cc}
\hline PMK & Penatausaha \\
No.120/PMK.06/20 & an BMN Itjen \\
07 tentang & Depdiknas \\
Penatausahaan & \\
BMN & \\
\hline
\end{tabular}

Pembukuan BMN
Pasal 8 s.d. pasal

13

Penatausahaan

BMN melakukan:

- pembukuan,

- menyimpan dokumen,

- membuat daftar barang kuasa pengguna (DBKP)

- melakukan pendaftaran dan pencatatan BMN ke dalam DBKP

- melaporkan DBKP kepada Pengelola Barang (UAPB)

Pasal 14 ayat 1

Dalam

penatausahaan BMN dibuat penggolongan dan kodefikasi untuk Setiap BMN Itjen

\begin{tabular}{|c|c|c|}
\hline \multirow{2}{*}{\multicolumn{3}{|c|}{ Inventarisasi BMN }} \\
\hline & & \\
\hline $\begin{array}{l}\text { Pengguna Barang } \\
\text { melakukan } \\
\text { inventarisasi } \\
\text { sekurang- }\end{array}$ & $\begin{array}{l}\text { Itjen } \\
\text { Depdiknas } \\
\text { sudah } \\
\text { melakukan }\end{array}$ & \multirow{8}{*}{$\begin{array}{l}\text { Penatausaha } \\
\text { an BMN Itjen } \\
\text { Depdiknas } \\
\text { sudah sesuai } \\
\text { ketentuan } \\
\text { yang berlaku }\end{array}$} \\
\hline kurangnya setiap 5 & inventarisasi & \\
\hline $\begin{array}{l}\text { tahun sekali dan } \\
\text { melaporkan kepada }\end{array}$ & $\begin{array}{lr}\text { Setiap } & 5 \\
\text { tahun, } & \text { sudah }\end{array}$ & \\
\hline $\begin{array}{l}\text { Pengelola Barang } \\
\text { dan mencatat hasil }\end{array}$ & $\begin{array}{l}\text { melaporkan } \\
\text { kepada }\end{array}$ & \\
\hline \multirow{4}{*}{$\begin{array}{l}\text { dan mencatat hasil } \\
\text { inventarisasi ke } \\
\text { dalam DBKP }\end{array}$} & Pengelola & \\
\hline & Barang dan & \\
\hline & $\begin{array}{l}\text { sudah } \\
\text { ke dicatat } \\
\text { dalam }\end{array}$ & \\
\hline & DBKP & \\
\hline Pasal 16 ayat 3 & Itjen & Penatausaha \\
\hline Data transaksi BMN & Depdiknas & an BMN Itjen \\
\hline
\end{tabular}

Depdiknas

belum

melakukan penggolonga

n dan

kodefikasi

untuk Setiap

BMN

Penatausaha
an BMN Itjen
Depdiknas
sudah sesuai
ketentuan
yang berlaku.

UAPPB-E1 setiap menyampaika

semester

n data

transaksi

BMN ke

UAPPB-E1

Setiap

semester

$\begin{array}{lll}\text { Pasal } 18 \text { ayat } 1 \& 2 & \text { Itjen } & \text { Penatausaha } \\ \text { UAPPB-E1 } & \text { Depdiknas } & \text { an BMN Itjen } \\ \text { menyusun Lap BMN } & \text { sudah } & \text { Depdiknas }\end{array}$

Eselon I

menyusun

Lap BMN Eselon I Lap BMN

disampaikan ke Eselon I dan

UAPB Setiap menyampaik

semester an ke UAPB

sudah sesuai

pencatataan

dan

elaporkan

DBKP kepada

Penatausaha an BMN Itjen Depdiknas belum sesuai ketentuan yang berlaku vang berlaku

Setiap

semester

Pasal 21 ayat $1 \& 2$ Itjen Penatausaha

Prosedur Depdiknas an BMN Itjen

pencatatan SABMN belum Depdiknas

dilaksanakan sesuai melaksanaka

prosedur $n$ pencatatan

Laporan BMN SABMN

dibuat sesuai sesuai

format dan bentuk prosedur dan

belum sesuai

ketentuan

baku yang belum

ditentukan menyusun

Laporan BMN

sesuai format

dan bentuk

baku

21

UAKPB menyusun

laporan semesteran

dan tahunan serta

menyampaikan

kepada UPPB-E1.

UPPB-E1 menyusun

laporan barang

pengguna eselon I

semesteran dan

tahunan

\section{Itjen}

Depdiknas

sebagai

UAKPB dan

Penatausaha an BMN Itjen

Depdiknas

UPPB-E1

sudah

menyusun

dan

sudah sesuai

ketentuan

yang berlaku

melaporkan

laporan

barang

pengguna

Setiap

semester dan

tahunan

Sumber: diolah dari berbagai sumber

\section{Pelaporan BMN \\ Pasal 19 dan Pasal}




\section{Evaluasi Penatausahaan BMN berdasarkan} Hasil Inventarisasi BPKP

Itjen Depdiknas dalam kuran waktu kurang dari lima tahun telah melaksanakan dua kali inventarisasi. Inventarisasi pertama dilaksanakan pada tahun 2005 dengan tujuan untuk mendapatkan saldo awal tahun 2006. Sedangkan inventarisasi kedua dilaksanakan tahun 2008 dengan tujuan menginventarisir pengadaan/perolehan aset tetap pada tahun 2006 dan 2007 yang dilaksanakan oleh BPKP. Hasil inventarisasi atas BMN Itjen Depdiknas ditemukan adanya selisih nilai sebesar Rp4.165.364.712 dengan Laporan BMN Itjen Depdiknas per 31 Desember 2017, sebagaimana Tabel 3. berikut:

Tabel 3. Perbandingan Inventarisasi BMN oleh BPKP dengan Laporan BMN Itjen TA

\begin{tabular}{|c|c|c|c|}
\hline \multicolumn{4}{|c|}{2007} \\
\hline $\begin{array}{l}\text { Jenis } \\
\text { BMN }\end{array}$ & $\begin{array}{c}\text { Hasil } \\
\text { Inventarisasi } \\
\text { BPKP } \\
\text { (Vol / Nilai } \\
\text { Rp) }\end{array}$ & $\begin{array}{c}\text { Laporan } \\
\text { BMN Itjen } \\
\text { Depdiknas } \\
\text { (Vol/Nilai Rp) }\end{array}$ & $\begin{array}{c}\text { Hasil } \\
\text { Evaluasi } \\
\text { Lap BMN } \\
\text { Itjen }\end{array}$ \\
\hline Tanah & $\begin{array}{l}12.578 \mathrm{~m} 2 / \\
105.311 .116\end{array}$ & $\begin{array}{l}12.578 \mathrm{~m} 2 / \\
105.311 .116\end{array}$ & $\begin{array}{c}\text { Sudah } \\
\text { sesuai } \\
\text { Inventarisa } \\
\text { si BPKP }\end{array}$ \\
\hline $\begin{array}{l}\text { Peralata } \\
\text { n dan } \\
\text { Mesin }\end{array}$ & $\begin{array}{c}5.763 \text { unit / } \\
27.968 .646 .3 \\
30\end{array}$ & $\begin{array}{c}6.004 \text { unit / } \\
33.244 .166 .6 \\
22\end{array}$ & $\begin{array}{c}\text { Tidak } \\
\text { sesuai } \\
\text { Inventarisa } \\
\text { si BPKP }\end{array}$ \\
\hline $\begin{array}{l}\text { Gedung } \\
\text { dan }\end{array}$ & $\begin{array}{c}20 \text { unit / } \\
20.548 .112 .1\end{array}$ & $\begin{array}{c}20 \text { unit / } \\
19.437 .956 .5\end{array}$ & $\begin{array}{c}\text { Tidak } \\
\text { sesuai }\end{array}$ \\
\hline $\begin{array}{c}\text { Banguna } \\
\mathrm{n}\end{array}$ & 50 & 70 & $\begin{array}{l}\text { Inventarisa } \\
\text { si BPKP }\end{array}$ \\
\hline $\begin{array}{l}\text { Jalan, } \\
\text { Irigasi } \\
\text { dan } \\
\text { Jaringan }\end{array}$ & 1 unit / 1 & 1 unit 1 & $\begin{array}{c}\text { Sudah } \\
\text { sesuai } \\
\text { Inventarisa } \\
\text { si BPKP }\end{array}$ \\
\hline $\begin{array}{c}\text { Aset } \\
\text { Tetap } \\
\text { Lainnya }\end{array}$ & $\begin{array}{l}1 \text { unit / } \\
850.000\end{array}$ & $\begin{array}{l}1 \text { unit / } \\
850.000\end{array}$ & $\begin{array}{c}\text { Sudah } \\
\text { sesuai } \\
\text { Inventarisa } \\
\text { si BPKP }\end{array}$ \\
\hline
\end{tabular}

Sumber: diolah dari berbagai sumber

Evaluasi atas Pengendalian Internal Penatausahaan BMN
Pengendalian internal BMN merupakan salah satu kebijakan Departemen Pendidikan Nasional yang dituangkan di dalam Prosedur Operasi Standar (POS) Sistem Informasi Depdiknas Tahun 2008. Hasil laporan inventarisasi BMN oleh BPKP dan dari hasil wawancara dengan pejabat dan pengelola BMN pada Itjen Depdiknas, ditemukan adanya pelaksanaan pengendalian internal atas penatausahaan BMN yang belum dilaksanakan sebagaimana Tabel 4 . berikut:

Tabel 4. Evaluasi pengendalian internal BMN pada Itjen Depdiknas

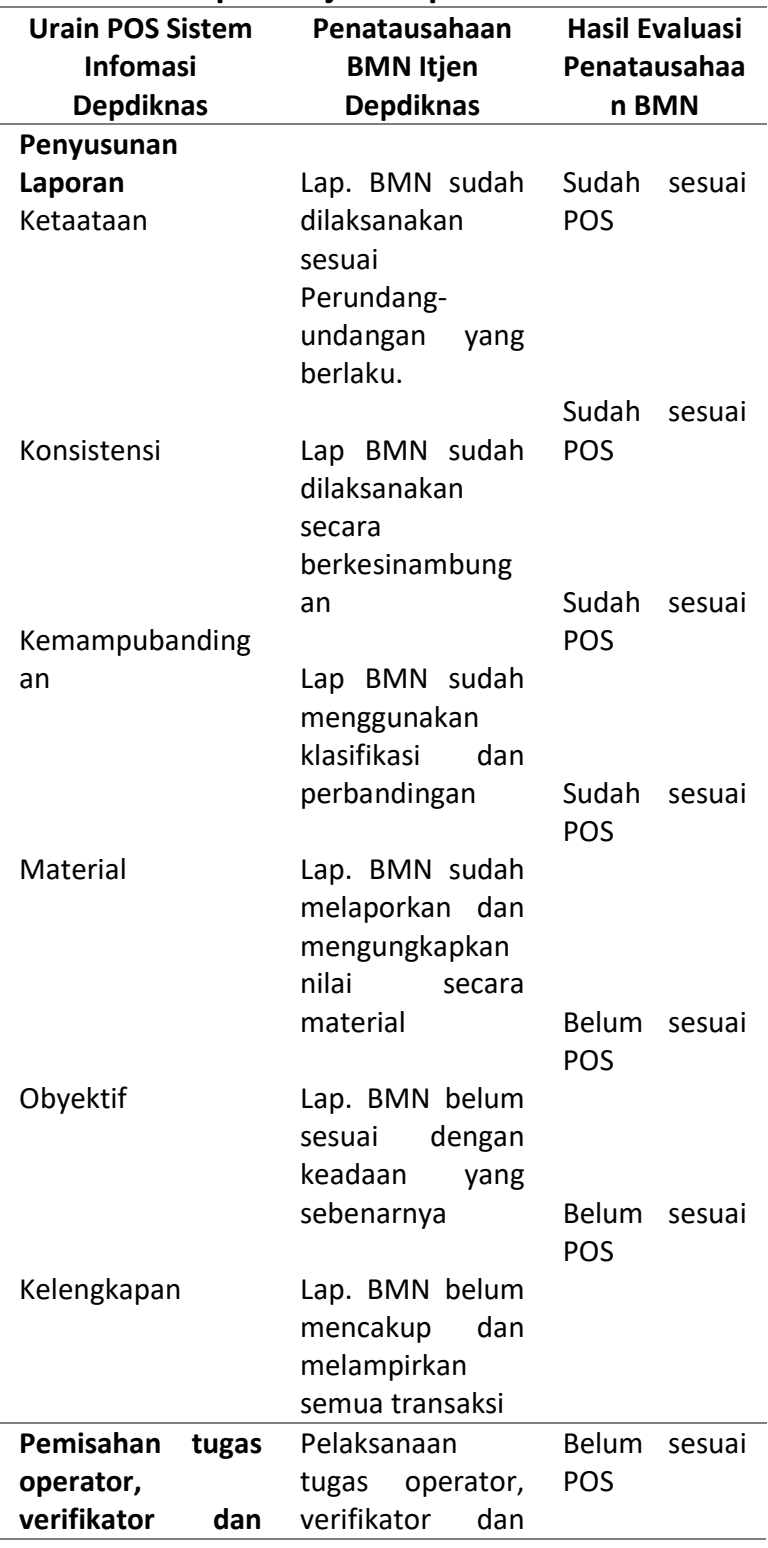




\begin{tabular}{|c|c|c|}
\hline $\begin{array}{c}\text { Urain POS Sistem } \\
\text { Infomasi } \\
\text { Depdiknas }\end{array}$ & $\begin{array}{c}\text { Penatausahaan } \\
\text { BMN Itjen } \\
\text { Depdiknas }\end{array}$ & $\begin{array}{c}\text { Hasil Evaluasi } \\
\text { Penatausahaa } \\
\text { n BMN }\end{array}$ \\
\hline validator & $\begin{array}{l}\text { validator } \\
\text { dipegang } \\
\text { rangkap oleh } \\
\text { satu orang }\end{array}$ & \\
\hline Dokumen Sumber & $\begin{array}{l}\text { Dokumen } \\
\text { sumber yang } \\
\text { digunakan adalah } \\
\text { dokumen sah }\end{array}$ & $\begin{array}{l}\text { Sudah sesuai } \\
\text { POS }\end{array}$ \\
\hline Pelaporan BMN & $\begin{array}{l}\text { Pelaporan BMN } \\
\text { dilaksanakan } \\
\text { secara berkala } \\
\text { dan berjenjang } \\
\text { dengan mengacu } \\
\text { peraturan } \\
\text { perundangan }\end{array}$ & $\begin{array}{l}\text { Sudah sesuai } \\
\text { POS }\end{array}$ \\
\hline $\begin{array}{lr}\text { Verifikasi } & \\
\text { terhadap } & \\
\text { dokumen } & \text { sumber } \\
\text { dan } & \text { Register } \\
\text { Transaksi } & \text { Harian } \\
\text { (RTH) } & \end{array}$ & $\begin{array}{l}\text { Dokumen } \\
\text { sumber telah } \\
\text { dilakukan } \\
\text { verifikasi, namun } \\
\text { belum semua } \\
\text { RTH dilakukan } \\
\text { verifikasi dengan } \\
\text { dokumen sumber }\end{array}$ & $\begin{array}{l}\text { Belum sesuai } \\
\text { POS }\end{array}$ \\
\hline $\begin{array}{l}\text { Rekonsiliasi } \\
\text { Internal setiap } \\
\text { bulan dengan SAK }\end{array}$ & $\begin{array}{l}\text { Sudah dilakukan } \\
\text { rekonsiliasi } \\
\text { internal dengan } \\
\text { SAK, namun } \\
\text { hanya Setiap } \\
\text { semester }\end{array}$ & $\begin{array}{l}\text { Belum sesuai } \\
\text { POS }\end{array}$ \\
\hline 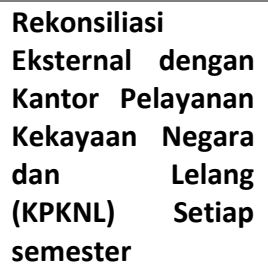 & $\begin{array}{l}\text { Sudah dilakukan } \\
\text { rekonsiliasi } \\
\text { eksternal dengan } \\
\text { KPKNL Setiap } \\
\text { semester }\end{array}$ & $\begin{array}{l}\text { Sudah sesuai } \\
\text { POS }\end{array}$ \\
\hline Inventarisasi & $\begin{array}{l}\text { Sudah dilakukan } \\
\text { inventarisasi } \\
\text { BMN selama } 2 \\
\text { kali dalam } \\
\text { periode } 5 \text { tahun }\end{array}$ & $\begin{array}{l}\text { Sudah sesuai } \\
\text { POS }\end{array}$ \\
\hline
\end{tabular}

Sumber: diolah dari berbagai sumber

\section{PENUTUP}

SIMPULAN

Hasil evaluasi atas penerapan penatausahaan Barang Milik Negara (BMN) terhadap Standar Akuntansi Pemerintah pada Kantor Itjen Depdiknas Tahun Anggaran 2008, penulis dapat mengambil simpulan sebagai berikut :
1. Penatausahaan $B M N$ pada Kantor Itjen Depdiknas belum seluruhnya sesuai dengan peraturan perundangan yang berlaku. Diantaranya adalah sebagai berikut:

a. Belum dibentuk struktur organisasi, pembagian tugas dan fungsi yang terkait dengan penatausahaan BMN yang diantaranya terditi dari Unit Akuntansi Kuasa Pengguna Barang (UAKPB) dan Unit Akuntansi Pembantu Pengguna Barang Eselon I (UAPPB-E1).

b. Pemisahan tugas dan fungsi antara UAKPB dan UAPPB-E1 hanya dibedakan pada siapa yang bertanggungjawab, sementara Sub bagian Tata Usaha Bagian Umum berperan sebagai UAKPB sekaligus UAPPB-E1 dalam menyiapkan laporan semester/tahunan.

c. Fungsi operator, verifikator dan validator belum dipisahkan secara jelas. Hal ini terlihat dari belum adanya Surat Keputusan Kepala satker yang mengatur fungsi-fungsi tersebut.

d. Dalam pembukuan Barang Milik Negara (BMN), Kantor Itjen Depdiknas mengklasifikasikan BMN yang dikuasainya ke dalam golongan, bidang kelompok, subkelompok sesuai dengan PMK Nomor 120/PMK.06/2007. Namun belum semua barang berupa aset tetap diberi label kode registrasi untuk membedakan barang yang satu dengan yang lainnya dan pemberian label kode registrasi yang ada belum sesuai.

e. Kapitalisasi yang berhubungan dengan pengakuan dan pengukuran BMN pada Kantor Itjen Depdiknas dilakukan dengan mengacu pada PMK Nomor 120/PMK.06/2007, yaitu transaksi atas aset tetap dan persediaan diakui ketika dokumen sumber diterima oleh petugas akuntansi barang. Aset tetap dan persediaan yang diperoleh dari pembelian diukur pada nilai perolehannya, sedangkan yang 
Sujatmiko Wibowo: Evaluasi atas Pengendalian Intern...

diperoleh dari hibah diukur pada nilai yang ditentukan oleh pemberi hibah.

f. Pengeluaran setelah perolehan aset tetap yang menambah masa manfaat atau membawa manfaat ekonomi di masa depan dikapitalisasi dan ditambahkan pada nilai aset tetap yang bersangkutan.

g. Inventarisasi terhadap aset tetap sudah dilakukan selama dua kali selama periode tahun 2006 sampai dengan tahun 2008 dengan dibantu oleh Tim Penertiban BMN Badan Pengawas Keuangan dan Pembangunan (BPKP), dan dijumpai selisih antara aset tetap yang ada dan yang tercatat di dalam aplikasi SABMN. Namun selisih tersebut sudah disesuaikan sesuai rekomendasi Tim Penertiban BMN BPKP. Selisih yang terjadi disebabkan petugas aplikasi BMN hanya terdiri dari 1 orang, sehingga tidak ada yang mengevaluasi dan mengecek ulang penginputan BMN ke dalam aplikasi SABMN.

2. Pengendalian internal di dalam penatausahaan BMN Kantor Itjen Depdiknas belum berjalan dengan baik. Diantaranya adalah sebagai berikut:

a. Penyusunan laporan BMN belum obyektif dan lengkap. Hal ini bisa dilihat dari belum semua laporan dibuat sesuai ketentuan perundang-undangan yang berlaku dan belum semua transaksi dicatat ke dalam aplikasi SABMN.

b. Belum dilakukan pemisahan tugas antara operator computer, verifikator, dan validator.

c. Belum dilakukan verifikasi dokumen sumber dengan Register Transaksi Harian (RTH), sehingga terdapat perbedaan antara dokumen sumber dan RTH yang mengakibatkan terdapat selisih/perbedaan antara laporan BMN dengan realisasi perolehan aset.

d. Belum dilaksanakan rekonsiliasi internal secara berkala (triwulan). Rekonsiliasi internal hanya dilakukan Setiap semester, sehingga neraca aset tetap pada Sistem Akuntansi Keuangan Pengguna Anggaran (SAKPA) belum menggambarkan keadaan yang sebenarnya.

\section{SARAN}

Memperhatikan kondisi penatausahaan BMN pada Kantor Itjen Depdiknas tersebut, peneliti menyarankan agar segera dibentuk organisasi pengelola unit akuntansi pada UAKPB dan UAPPB-E1 sehingga pembagian wewenang, tugas dan tanggung jawab terkait penatausahaan BMN menjadi lebih jelas. Disamping itu, kompetensi sumber daya manusia dan pengendalian internal di dalam penatausahaan $B M N$ agar lebih ditingkatkan sehingga BMN dapat dikelola dan ditatausahakan dengan lebih transparan dan akuntabel.

\section{KETERBATASAN PENELITIAN}

Penelitian ini hanya menggunakan data laporan BMN dan Laporan Hasil Inventarisasi BPKP pada periode akuntansi per 31 Desember 2007 dan hanya dilakukan pada Kantor Itjen Depdiknas yang merupakan salah satu satuan kerja di lingkungan Departemen Pendidikan Nasional sehingga belum dapat memberikan gambaran kondisi penatausahaan BMN yang terjadi pada Departemen Pendidikan Nasional secara menyeluruh.

\section{REFERENSI}

Bungin, B. (2007). Penelitian Kualitatif (Komunikasi, Ekonomi, Kebijakan Publik, dan IImu Sosial Lainnya). Jakarta: PT Kencana Prenada Media Group.

Chariri, A. (2009). Landasan Filsafat dan Metode Penelitian Kualitatif, Paper disajikan pada Workshop Metodologi Penelitian Kuantitatif dan Kualitatif, Laboratorium Pengembangan Akuntansi (LPA). Semarang: Fakultas Ekonomi Universitas Diponegoro.

Committee of Sponsoring Organizations of the Treadway Commission (COSO). (1992). 
Internal Control Integrated Framework. Tersedia di www.coso.org

Hasanah, N. dan Fauzi, A. (2016). Akuntansi Pemerintahan. Jakarta: In Media.

Harwida, Gita A. (2014). Mengulik Peran Auditor Internal Dalam Melakukan Deteksi Dan Pencegahan Fraud Di Perguruan Tinggi. Jurnal Infestasi Vol. 11 No. 1 Tahun 2015, E-ISSN 2460-8505, hlm. 56-72.

Indriantoro, et al. (2002). Metodologi Penelitian Bisnis Untuk Akuntansi dan Manajemen. Edisi Pertama. Yogyakarta: BPFE.

Mursyidi. (2009). Akuntansi Pemerintahan di Indonesia. Bandung: PT Refika Aditama.

Murtanto. (2005). Sistem Pengendalian Internal Untuk Bisnis. Jakarta: PT Hecca Mitra Utama.

Moleong. Lexi J. (2004). Metodologi Penelitian Kualitatif. Bandung: PT Remaja Rosdakarya.

Panggabean, M. (2014). Analisis Pengaruh Sistem Pengendalian Internal Terhadap Pengawasan Internal dalam Perspektif Chaos Theory di Kementerian Pendidikan dan Kebudayaan, Disertasi. Jakarta: Universitas Indonesia.

Pardiman dan Ula, Muh U. (2009). Penataan Pengelolaan Barang Milik Negara (BMN) yang Tertib dan Akuntabel sesuai Kaidah-Kaidah Good Governance, Artikel Ditjen Kekayaan Negara. Jakarta: Kementerian Keuangan. Tersedia di: www.djkn.kemenkeu.go.id

Qolbi, N., et al. (2012). The Importance Of The Government Procurement Officers's Competence In Bangkalan Regency In Implementing The Procurement Procedure In The Precidential Decree 54 Of 2010; Proceeding pada A4FM AsiaAmerica-Africa- Australia Public Finance Management Conference. Surabaya: UPN.

Republik Indonesia, 2008, Prosedur Operasi Standar Sistem Informasi Manajemen
Depdiknas, Biro Keuangan Setjen Depdiknas, Jakarta

Republik Indonesia, 2008, Laporan Keuangan Inspektorat Jenderal Depdiknas Tahun 2008, Itjen Depdiknas, Jakarta

Republik Indonesia. (2007). Sistem Pengendalian Manajemen. Jakarta: Pusdiklatwas BPKP.

(2003). Undang-

Undang Nomor 17 Tahun 2003 tentang Keuangan Negara

(2004). Undang-

Undang Nomor 1 Tahun 2004 tentang Perbendaharaan Negara

(2004). Undang-

Undang Nomor 15 Tahun 2004 tentang Pemeriksaan Pengelolaan dan Pertanggungjawaban Keuangan Negara (2005). Peraturan Pemerintah Nomor 25 Tahun 2005 tentang Standar Akuntansi Pemerintahan

(2005). Peraturan Menteri Keuangan Nomor 59/PMK.06/2005 tentang Sistem Akuntansi dan Pelaporan Keuangan Pemerintah Pusat - (2006). Peraturan Pemerintah Nomor 6 Tahun 2006 tentang Pengelolaan Barang Milik Negara/Daerah

(2008). Peraturan

Pemerintah Nomor 60 Tahun 2008 Tentang Sistem Pengendalian Internal Pemerintah

Menteri Keuangan Nomor 120/PMK.06/2007 tentang

Penatausahaan Barang Milik Negara (2005). Peraturan

Menteri Pendidikan Nasional Nomor 12 Tahun 2005 tentang Struktur Organisasi dan Tata Kerja Inspektorat Jenderal Depdiknas

(2008). Peraturan Menteri Pendidikan Nasional Nomor 16 
Sujatmiko Wibowo: Evaluasi atas Pengendalian Intern...

Tahun 2008 tentang Sistem Akuntansi dan Pelaporan Keuangan di Lingkungan Departemen Pendidikan Nasional

Siregar, D. (2004). Manajemen Aset. Jakarta: PT Kresna Prima Persada.
Yin, Robert K. (2009). Case Study Research: Design and Methods (4th Ed.), Thousand Oaks, Sage, CA. 